\title{
REFLECTIONS ON ADOLESCENCE AND HEALTH IN THE SCHOOL ENVIRONMENT
}

\author{
Maria Augusta Rocha Bezerra ${ }^{1}$, Maria Veraci Oliveira Queiroz², \\ Karla Nayalle de Souza Oliveira ${ }^{3}$
}

\begin{abstract}
Objective: to identify the approach to health issues and adolescence among adolescents of a Federal Technical School and discuss the issues raised by them during an educational program, encouraging thinking on how better to experience adolescence. Method: the study had as its theoretical methodological framework the research-action, undertaken at a federal school in Bom Jesus-PI, Brazil, in May and June 2010, with the participation of nine adolescents. Results: the results showed that the students attributed different meanings to adolescence, with an emphasis on the physical and psychological changes involved. They demonstrated doubts about this stage of life; they considered their colleagues to be their main source of information on adolescence and health, although they regarded the school as the most appropriate place to obtain such knowledge. Conclusion: the urgent need for teachers and school to engage in debates on questions related to adolescence and health is emphasized, since their school is where teenagers spend most of their time.
\end{abstract}

Key Words: Adolescent; School Health; Health Promotion.

\section{INTRODUCTION}

Adolescence is an important phase of human development which is marked by peculiar biopsychological characteristics related to the body's growth, sexual maturity and interpersonal relationships and which shows the social context to be a significant factor for the formation of the young person as a subject of values and attitudes ${ }^{1}$. The adolescent condition extends in accordance with the projections which the adolescent receives from adults and the limits of the exploitation imposed by society ${ }^{2}$.

Within this perspective, adolescence is part of a much broader cultural phenomenon than the variations of age established for it, whether by the World Health Organization (WHO) or by the Ministry of Health (which adopts the former's proposal) and the Statute of the Child and the Adolescent (ECA), seeing that it does not present evident characteristics of a beginning or an ending. However, alleging the need to delimit it for the purposes of planning, adolescence is defined by the WHO as the period of life between 10 and 19 years of age and by the ECA as extending from 12 to 18 years $^{3}$.

To continue the discussion, adolescence may be understood as the period characterized by constant psycho-physiological transformations and maturation, contradictions, ambivalence, turbulence, is full of passions, painful and characterized by conflicts of relationships within the family and the social context ${ }^{4}$. Among the most common associated situations of vulnerability may be quoted: unwanted pregnancy, Sexually Transmissible Diseases (STD), experimentation with drugs, exposure to accidents as a consequence of imprudent behavior, as well as to various forms of violence ${ }^{5}$.

It is for these reasons that it is essential that the questions related to adolescent health should be debated beyond the specific sectors concerned, i.e., the health units and hospitals, because of the importance of the approach to the subject in relation to the various spaces in which the adolescent lives with his peers.

1 Mestre em Saúde da Criança e do Adolescente da Universidade Estadual do Ceará (UECE). Docente do Curso de Bacharelado em Enfermagem da Universidade Federal do Piauí. End: BR 343, Km 3,5, Bairro Meladão, Campus Amilcar Ferreira Sobral, CEP: 64.800-00, Floriano, Piauí, Brasil.

2 Doutora em Enfermagem. Docente do Curso de Graduação em Enfermagem da UECE. End: Rua Barbosa de Freitas, no 941, Apto. 1101. Bairro Meireles, Fortaleza, Ceará, Brasil.

3 Especialista em Enfermagem em Saúde do Trabalhador. Professora do Curso Técnico em Enfermagem da Universidade Federal do Piauí (UFPI). End: BR 135, Km03, Bairro Planalto Horizonte, Campus Professora CinobelinaElvas, CEP: 64900-000, Bom Jesus, Piauí, Brasil.

Extraído da dissertação Adolescentes de uma escola técnica e o sentido da formação profissional: enfoque na pesquisaação, apresentado para o Mestrado Profissional em Saúde da Criança e Adolescente, na Universidade Estadual do Ceará, em 2011.

Corresponding author: mariaaugusta@ufpi.edu.br

Suggested citation: Bezerra MAR, Queiroz MVO, Oliveira KNS. Reflections on adolescence and health in the school environment, Journal of Human Growth and Development, 24(2): 175-180

Manuscript submitted Aug 01 2013, accepted for publication Dec 282013. 
It is, therefore, necessary to develop spaces in which adolescents may not only receive information but may also talk about themselves, discuss subjects of their interest and express their sentiments, that is to say, where they will be treated as special. Although it is important to focus on the subject with others, the adolescents will find it easier to express themselves with their peers, seeing that their friends are, according to most research projects, the group with which the adolescents themselves feel freest to talk about themes relating to adolescence ${ }^{6}$.

The results presented by research emphasize the importance of the actions undertaken with adolescents being conducted in groups, so that they may realize the need for the transformation of reality and a change of behavior in order to adopt healthy habits and positive attitudes ${ }^{7}$. Further, according to the Ministry of Health, group activities should have priority in this age group, because of the therapeutic character which the group possesses, making it a preferential space for the promotion of health ${ }^{8}$.

Thus, among the possible spaces for the approach to the subtleties involved in the question of adolescent life and experience, as well as in aspects which can influence this process, stands the school, a point of reference for the implementation of the programs directed to education and consciousness, also as related to health, enshrined in the National Curricular Parameters (Parâmetros Curriculares Nacionais) by the Ministry of Education in 1997, as a crosssectional theme to be worked on, as far as may be possible, within school subjects.

The school has a fundamental role to play in the development of the adolescent, contributing to his all-round training as also, thus, to that of society. This is a role which goes beyond the act of teaching and involves the education of the child and the adolescent, developing their identity and individuality ${ }^{9}$. Therefore, within the context of the debate between adolescence, health and school, the questioning which guided the research emerged: how do these adolescents perceive themselves and the process of adolescence?

This study made it possible for the adolescents involved to experience a process of reflection which favored the promotion of a critical vision on adolescence and the questions pertinent to their health. Despite the research's having been undertaken in an institution of integrated intermediate and technical teaching, traditionally directed to professional training, we were permitted to emphasize that the adolescents involved, as well as being young people undergoing professional training, were also still growing up. By promoting discussions on the effective implementation of transversal themes in teaching institutions, one raises in an innovative way proposals which will stimulate teachers to exercise activities which address the themes adolescence and health.

The objective is thus to identify the approach to the themes health and adolescence with adolescents and list subjects indicated by them by means of an educative program.

\section{METHODS}

This is a qualitative approach which adopted research-action as its method, undertaken in a federal school in Bom Jesus, Piauí. The Federal Institution of Technical and Technological Instruction (Instituição Federal de Ensino Técnico e Tecnológico) in the period in which the data were collected, in May and June 2010, had a total enrolment of 378 students, divided among the three technical courses offered (Farming and cattle raising, Nursing, and Information Technology), undertaken either simultaneously or sequentially.

The subjects of the study were adolescents (in accordance with the WHO proposal, of 10 to 19 years of age) who were taking the $2^{\text {nd }}$ year of Intermediate Education, concomitantly with the $1^{\text {st }}$ year of the Technical Course in Farming and Cattle raising, Nursing, or Information Technology. Nine adolescents who chose the following groups of themes for discussion: adolescence and health and school/professional training, participated in the project. This article presents the summary of the original theme: adolescence and health.

The inclusion criteria were: being regularly matriculated in one of the grades of Intermediate Education and in one of the above-mentioned technical courses, and willingness to participate voluntarily in the project, with the consent of the person responsible, attested by the signing of the Voluntary Enlightened Consent Form.

The survey of the seminal themes, culminating in the exposition of the problems raised related to adolescence and health, was undertaken by means of individual interviews in accordance with a semi-structured protocol. This instrument consisted of guiding questions which sought to facilitate the expression of difficulties on the part of the persons being studied. The collection of these data lasted a week, thus allowing each adolescent to expound his/her doubts. Once the survey of the scope of the themes had been completed, the educational activities were drawn up - which was the moment at which the teaching plans related to the seminal themes and the assessment of the process were elaborated. This plan, which resulted in the Educational Program, formulated on the basis of these proposals, was then implemented starting with the codified problem-situations which were then decodified by the adolescent students being investigated and the researcher/instructor. The debate on the themes led to the group's reflections.

Various activities were undertaken, it being possible to adapt the plans for the approach of the pedagogical workshops with texts and cuttings, thus stimulating the search for reflection and the construction of knowledge and abilities. The assessment of the process was conducted by the reading of the adolescents' records, of the 
satisfaction expressed regarding the strategies referred to in the discourses in the final stage of the Educational Program by means of the replies given to the questions.

The educational program was divided into six days and consisted of eight moments, each meeting having an average duration of two hours. The moments of the program were divided into: presentation, interaction, investigation, theorization, sensibilization/problematization, learning/experiencing and assessment ${ }^{10}$.

The data were collected by the use of asystematic observation techniques and registered in a field diary, and interviews were held for the initial approach to the group of adolescents with whom it was planned to work and investigate the themes of interest to the participants.

The information previously collected during the planning for the meetings was compiled at a first moment during the analysis of the empirical material. The organization of the data obtained corresponded to the themes suggested by the participants. In the analysis, the meanings elaborated by the adolescents regarding their experiences, such as the nuances related to adolescence and health, were interpreted.

Four categories emerged on the basis of the analyses. Meanings of adolescence, Doubts about adolescence, Dialogs on questions of adolescence and health, and Approach to the questions of adolescence and health in the school.

This study satisfied the ethical principles involved in research on human beings, in accordance with Resolution 196/9611, being approved by the Ethics in Research Committee of the Federal University of Piauí, as opinion nr. 0088/ 2011. The document of Free and Enlightened Consent was signed by the participants and those legally responsible for them.

\section{RESULTS}

\section{Meanings of adolescence}

On this theme the adolescents talked about themselves and expressed the meaning of adolescence on the basis of their social relationships, daily experiences, feelings, worries and perceptions of this phase.

The group investigated consisted of seven students of the technical course in Nursing, one of the Information Technology course and one other of the Farming and Cattle raising course. The predominant age range was of 15 and 16 years, the majority were of feminine sex, as regards sexual orientation - heterosexual; living in the urban zone, in general with their parents, with a monthly family income of two legal minimum salaries. The adolescents reflected on themselves and the process of adolescence.

[...] a phase in which many doubts arise in the adolescent is mind; it is a phase in which you discover many good and some bad things. (A1)

[...] a phase of discovery, in which adolescents are usually regarded as trouble some. (A2)
[...] a phase during which our thinking and the way in which react changes. (A4)

A phase of physical and psychological changes [...]. (A8)

Each adolescent was asked, when the Educational Program was underway, to imagine the part of his/her body which best represented adolescence for him/her and that then each one should draw it on a sheet of paper. At first, the adolescents were shy, then they played with each other about what they were drawing, but, finally, they got involved in the dynamic and joined in the discussion which followed.

They were told to place their drawings upside down and then that they should rotate them clockwise, until asked to stop. Then, each adolescent, with the drawing of another participant in his/her hands, should describe what he had understood from the printed figure, commenting and showing what the person had succeeded in transmitting by means of the mental image.

I think that the adolescent must have style, with a cool hairdo [...] but I know that in fact he is really beautiful inside [moved]. (A9)

I think that she drew a backside because that's what the boys like: the other day I was passing with a friend (a girl) and the boys said, Look at that BBS there; there, did I say BBS? And they said, Yes, what a Beautiful Back-Side. (A6)

[...] that is because the television say sit's beautiful, to have a well-developed body! (A5)

\section{Doubts about adolescence}

As regards doubts about adolescence, the participants were asked to relate or write down the doubts they had about the process of adolescence, with a view later to promoting an open and enlightening debate about their existing doubts. The adolescents showed doubts mainly about sex and sexuality.

Sex and sexuality, unwanted pregnancy. (A1) Unwanted pregnancy, what it is best to do if your parents don't accept abortion. (A3)

[...] sexuality, I'dlike tounder stand homosexuals, how this comes about and how it canhap pen. (A7)

\section{Dialogs on the questions of adolescence and health}

On the basis of the doubts presented by the adolescents, their sources of reference and confidence as regards aspects of life and the process of adolescence were investigated.

With friends, because I feel more at ease. (A2)

With other adolescents [...], because they understand me better. (A9)

With my adult (female) cousins, because they have more experience and also because I'm afraid to discuss it with my parents. (A1)

\section{Approach to questions of adolescence and health at school}

The lack of reference to teachers as sources of information on subjects related to the process 
of adolescence stood out as a factor of concern, despite the students having stated explicitly, almost unanimously, the importance of debating such subjects in teaching institutions. This demonstrates that the teachers, even sharing the larger part of the day with their students (seeing that the institution in question gives full-time teaching), had still not succeeded in establishing an effective link with the adolescents.

In the attempt to clarify the reasons for the difficulty in establishing dialog between teachers and students, an approach was made by questioning the students about it to ascertain how communication took place.

As regards the above problem, when encouraged to present opinions about the approach to themes related to adolescence in the teaching institution, the participants said they had received information on the questions involved in adolescence and/or health in the school setting. As to the themes dealt with, they quoted: sex and sexuality (mentioned by participants $A 1, A 6$, A9); health - unspecified aspects (mentioned by participant A2); alcohol and drugs (cited by adolescents A4, A6) and eating habits (referred to by student $A 7$ ).

Concerning the school subjects in which the themes mentioned had been commented on, the adolescents mentioned: Microbiology (discipline of the Nursing Technician course, referred to by participant A1); Biology (in the Intermediate Teaching course, mentioned by students A2, A8, A9); Composition Writing (in the Intermediate Teaching classes, quoted by adolescents A3, A4, A6); Nutrition (Nursing Technician course, mentioned by student A7); within various disciplines (referred to by participant A5).

\section{DISCUSSION}

The reports revealed various meanings attached to adolescence, these being related, in a general way, to transformation, whether concerning changes in the body, or discoveries, of interpersonal relationships or to changes in thinking and acting, a situation which occurs naturally in this phase and includes discoveries about oneself and the world.

Further, the adolescents presented their conceptions on this phase, even though simply. The acquisition of this knowledge arose from the literature used in the disciplines studied or from present-day mass media.

Adolescents undergo a dynamic and complex process on the path to maturity. The bodily transformations, the development of cognitive abilities and their new role in society lead them to question the values of the adults around them. Thus the external setting and social interactions influence the thinking of the adolescents directly, exercising a preponderant influence in their behavior and attitudes ${ }^{12}$.

During the carrying through of the Educational Program, in the first meeting dedicated to its implementation, it was sought to discover the perception of the students relating to adolescence, by means of the use of the Mental Image technique ${ }^{13}$ (ANNEX 1). The purpose of this activity was to illustrate the themes, leading to reflection which would make what they had expounded in the previous experience clearer.

The use of the dynamic based on the preparation of drawings was not intended to investigate, psychologically, what the illustrations represented, but to facilitate dialog and reflection on the theme under discussion - adolescence.

The students characterized in their drawings, the face, buttocks and eyes as the segments of the body which best represented adolescence. In the adolescents' comments they said that their choices were due to the perception that, for them, the changes which occurred in this phase were related mainly to these regions, because of the importance which the media gave to the exploitation of the body.

As regards the body, every adolescent has in his/her mind an idealized body. The further removed this body is from reality, the greater will be the possibility of conflict, compromising the person's self-esteem ${ }^{14}$. Thus, the adolescent is constantly preoccupied with his/her image, seeking to incorporate the ideal of beauty imposed by society, that is to say, the slender body. In consequence, at the present time, one observes an increase in the quest for the beauty and the models proposed for the perfect body by the fashion, goods and services segments ${ }^{15}$.

The ideal model of the body promoted by contemporary society calls for lean, slender bodies for girls and strong, muscular ones for boys. So those who deviate from this ideal are fated to live with failure and dissatisfaction. This dissatisfaction can have repercussions in the way in which the adolescent relates to his/her body, determining whether he/she accepts it and incorporates it as a new and definitive entity ${ }^{16}$.

The threat of social stigma should the adolescent diverge from the thin and symmetrical body which society imposes as the standard of beauty, leads him/her to seek this supposedly perfect stereotype, a quest which may generate problems related to the body image ${ }^{17}$.

Sexuality is one of the most important aspects of the life of a man or a woman. In the light of this, the ever more constant propagation by the media of sex and eroticism encourages precocious sexual initiation - and its banalization ${ }^{18}$.

In adolescence, this interest becomes even more accentuated, seeing that it is precisely in this phase that young people have doubts about questions related to the body and sexuality and, in general, because they cannot find up-to-date educational materials presented in simple, objective language, or the right place or people able to clarify their doubts ${ }^{13}$.

Their friends, that is to say, other adolescents, appear as their main sources of information and exchange of knowledge about adolescence. It is from their colleagues, in conversation with them, that they learn most about adolescence. Others referred, indirectly, to 
brothers and cousins who, generally speaking, are in an age-group close to theirs and are regarded as equals.

The importance which adolescents attribute to their friends as regards conversations on adolescence and related subjects, such as those related to sexuality, is thus clear. The participants in the research project expressed at various times the fact that their friends were the main sources for the clarification of doubts at difficult moments. For the participating adolescents, this was due to the fact that, as they were of approximately the same age as themselves, their friends understood the problems of adolescence better than anyone else. However, for the majority of the adolescents, at this moment, their parents were not without importance or value, though other instances and other groups are of fundamental value in the life of the young people ${ }^{14}$.

The insufficient reference on the part of the interviewees to their teachers as a source of information is noteworthy, this observation pointing to the need for the greater awareness and preparation of instructors to deal adequately with questions related to the process of adolescence in their pupils' daily routine, seeing that it is they who spend the greatest time with the students, and this calls for adequate technical ability to enable them to approach the themes related to adolescence 18

In recent years in Brazil, government initiatives have sought, systematically and definitively, to articulate actions between the health and education sectors which have been meeting difficulties in the implementation of efficacious strategies, even when health is included among the educational themes to be dealt with by teachers at all levels in teaching institutions (including the Federal Network of Professional and Technological Education)..

The comments presented revealed, further, that despite the students having referred to discussion on the themes related to the process of adolescence in their intermediate level or technical classes, many of them were unable to specify or could not remember what had been taught.

Beyond that, another point that deserves attention as regards the disciplines in which the themes were approached related to those most often mentioned as having a curricular content similar to health, such as the specific subjects of the Nursing Technician course and Biology. It is worth noting, however, as a positive change in the activity of the school, the inclusion of the subjects abortion and the use of alcohol and other drugs in the discipline Composition Writing.

The larger part of the explanations given in reply to the questioning of the adolescents when these are raised in the school occur in the disciplines of the Sciences and Biology, but the themes dealt with are not treated as crosssectional ${ }^{18}$

The instructor, already overloaded with tasks, does not feel him/herself to be adequate to exercise functions related to preventive medicine. There are difficulties involved in interacting with health professionals, as there are no professionals available at the Health Unit closest to the school and when health courses are offered they are addressed specifically to Biology or Science teachers, which reinforces the divorce between Health and Education ${ }^{19}$.

Even so, schools do seek gradually to include in their pedagogical practice fundamental questions related to the promotion of health ${ }^{20}$. This insertion is essential, because the school is a privileged space as it brings together, for a considerable period of time, children and adolescents at a critical phase in their growth and development ${ }^{21}$.

The results of this present study demonstrate, therefore, the need to include themes related to adolescence in the school environment. It is necessary, however, to express certain restrictions. First, as one is here dealing with a qualitative study, which seeks meanings attributed by the subjects of the research and permits reflection, it must be remembered that within this perspective the objectives set for the activity were achieved, it having been possible to awaken students to the need to debate questions related to health and the process of adolescence, not only with colleagues and in leisure spaces, but also at school with their teachers, as was clearly stated at the end of the research activities. However, the investigation, although it stimulated reflection which can provide elements for instructors and improve teaching practice, reveals its limitations and demonstrates the urgency of the need for studies dealing with these adolescents, as both school and teachers need to be prepared to address the themes dealt with during the school's daily routine.

Thus, in future investigations, qualitative and participative methodologies (as used in this research) addressed to the other pole of the process (school/teacher) would help to a better understanding of other relevant aspects of the subject for the promotion of students' health within the school space.

\section{FINAL CONSIDERATIONS}

The participants attributed to adolescence the meanings of bodily changes and discoveries, clarifying theoretical content and common sense. Doubts were expressed about this phase of life and questions related to health, especially to sex and sexuality. They emphasized that other adolescents were the people with whom they most discussed the subject and from whom they learned most with regard to themes involving the process of adolescence and health. Even though they declared that subjects relating to adolescence were dealt with in school, the study demonstrated only an incipient approach on the part of the institution to the exploitation of these themes within the school setting. 
The adolescent participants considered the school to be the best place for the approach to and discussion of aspects of adolescence and health. They emphasized the importance of these teaching institutions' being able to teach and having teachers trained and involved in these questions, seeing that these instructors spent the greater part of their time with these pupils.

\section{REFERENCES}

1. Ferreira MA, Alvim NAT, Teixeira MLO, Veloso RC. Saberes de adolescentes: estilos de vida e cuidado à saúde. Texto \& Contexto Enferm. 2007; 16 (2): 217-24.

2. Dolto F. A Causa dos Adolescentes. São Paulo: Ideias e Letras; 2004. p. 24.

3. Bastos OM, Deslandes SF. Adolescer com deficiência mental: a ótica dos pais. Ciência e Saúde Coletiva. 2009; 14(1): 79-87.

4. Moreira TMM, Viana DS, Queiroz MVO, Jorge MSB. Conflitos vivenciados pelas adolescentes com a descoberta da gravidez. Rev Esc Enferm USP. 2008; 42(2): 312-20.

5. Beserra EP, Pinheiro PNC, Alves MDS, Barroso MGT. Adolescência e vulnerabilidade às doenças sexualmente transmissíveis: uma pesquisa documental. J Bras Doenças Sex Trans. 2008; 20(1): 32-5.

6. Brêtas, JRS, Ohara, CVS, Jardim, DP, Muroya, RL. Conhecimentos de adolescentes sobre Doenças Sexualmente Transmissíveis: subsídios para prevenção. Acta Paul Enferm 2009; 22(6): 786-92

7. Macedo, EOS, Conceição, MIG. Ações em grupo voltadas à promoção da saúde de adolescentes. Journal of Human Growth and Development. 2013; 23(2): 222-230

8. Brasil. Ministério da Saúde. Secretaria de Atenção em Saúde. Departamento de Ações Programáticas Estratégicas. Diretrizes nacionais para atenção integral à saúde de adolescentes e jovens, na promoção, proteção e recuperação da saúde. Brasília: Ministério da Saúde, 2010; p.43-49, 132p.

9. Roehrs H, Maftum MA, Zagonel IPS. Adolescência na percepção de professores do ensino fundamental. RevEscEnferm USP. 2010; 44(2):421-8.

10. Pereira KC. Sexualidade na Adolescência: Trabalhando a Pesquisa-Ação com Referenciais Teórico Metodológicos de Paulo Freire [dissertação]. São Paulo (SP): Escola de Enfermagem de Ribeirão Preto, Enfermagem Psiquiátrica; 2007. p. 89-95

11. Conselho Nacional de Saúde. Resolução n. 196 , de 10 de outubro de 1996. Dispõe sobre diretrizes e normas regulamentadoras de pesquisas envolvendo seres humanos. Bioética. 1996; 4(2 Supl):15-25.
This study brought out the need to develop joint strategies (between the health, school and community sectors) for the effective implementation of transversal themes in teaching institutions, in accordance with the proposal of the National Curricular Parameters (Parâmetros Curriculares Nacionais) so that teachers may be trained to exercise activities which address themes related to adolescence and health.

12. Grossman E, Ruzany $M H$, TaquetteSR. A consulta do adolescente e jovem. In: Ministério da Saúde (BR). Secretaria de Atenção à Saúde. Departamento de Ações Programáticas Estratégicas. Saúde do Adolescente: Competências e Habilidades. Brasília: Ministério da Saúde; 2008. v. 1. p. 41-46.

13. Prioto EP. Dinâmicas de grupos para adolescentes. Petrópolis: Vozes; 2008. 312p.

14. Valença, CN, Germano, RM. Percepção da auto-imagem e satisfação corporal em adolescentes: perspectiva do cuidado integral na enfermagem.Rev. Rene. Fortaleza. 2009; 10(4):173-80.

15. Witt JSGZ, Schnider AP. Nutrição Estética: valorização do corpo e da beleza através do cuidado nutricional. Ciênc Saúde Coletiva. 2011; 16(9): 3909-16.

16. Conti MA, Gambardella AMD, Frutuoso MFP. Insatisfação com a imagem corporal em adolescentes e sua relação com a maturação sexual. RevBras Crescimento DesenvolvHum. 2005; 15(2): 36-44.

17. Braga, PD, Molina, MCB, Figueiredo, TAM. Representações do corpo: com a palavra um grupo de adolescentes de classes populares. Ciência \& Saúde Coletiva. 2010; 15(1):87-95.

18. Moizés JS, Bueno SMV. Compreensão sobre sexualidade e sexo nas escolas segundo professores do ensino fundamental. Rev Esc Enferm USP. 2010; 44(1): 205-12.

19. Santos KF, Bogus CM. A percepção de educadores sobre a escola promotora de saúde: um estudo de caso. Rev Bras Crescimento desenvolv Hum. 2007; 17(3): 123-33.

20. Branco VMC, Melges SB, Medeiros DC, Phebo LB, Coutinho MFG. Saúde do Adolescente no Município do Rio de Janeiro: escolas como parceiras privilegiadas. In: Ministério da Saúde (BR). Organização Pan-Americana da Saúde. Escolas promotoras de saúde: experiências do Brasil. Brasília: Ministério da Saúde; 2006. (Série Promoção da Saúde, n. 6. p. 170-80)

21. Cerqueira MT. A Construção da Rede Latino Americana de Escolas Promotoras de Saúde. In: Ministério da Saúde (BR). Organização Pan-Americana da Saúde. Escolas promotoras de saúde: experiências do Brasil. Brasília: Ministério da Saúde; 2006. (Série Promoção da Saúde, n. 6. p. 33-9) 